\title{
Between Tradition and Modernity: Judaism on the Move
}

\author{
Nitza Davidoivitch ${ }^{1}, \&$ Ruth Dorot ${ }^{2}$ \\ ${ }^{1}$ Education Department, Ariel University, Ariel, Israel \\ ${ }^{2}$ School of Architecture, Ariel University, Ariel, Israel \\ Correspondence: Nitza Davidovitch, Education Department, Ariel University, Ariel, Israel. Tel: 972-54-777-6431. \\ E-mail: d.nitza@ariel.ac.il
}

Received: December 30, 2020

Accepted: March 11, 2021

Online Published: January 31, 2022

doi:10.5539/ass.v18n2p17

URL: https://doi.org/10.5539/ass.v18n2p17

\begin{abstract}
In this study we will discuss works of Israeli modern composers who set traditional prayers (piyut) to music. People are poised between tradition and modernity - always yearning for meaning and striving for the transcendental, the eternal. We will discuss the modern interpretations of individual and congregational prayers and the role that these composers, who intertwine old and new, play in contemporary communities, in and outside Israel.

This study is of cultural significance, today more than ever. The digital generation, born into a reality where the computer serves as the backbone of its lifestyle, the generation for whom social isolation has become part of the daily routine - years to find an anchor in its life - one of tradition, of the heritage of generations, which has the potential to give support and meaning to human existence. In a world ruled by uncertainty, tradition and culture, both particular and universal, offer a genuine key to life's treasures. In this way man finds himself part of the chain of generations. He is connected. He has a cultural identity. The song of the synagogue, the liturgical song of man to God, has become the song of the crowd, and the song of man to man.
\end{abstract}

Keywords: tradition, modernity, culture, digital generation, piyut, liturgical song

\section{Introduction}

\subsection{The Problem}

The tremendous technological development that has taken place throughout the twentieth and early twenty-first centuries has altered conventions, behaviors, customs, and events in our lifestyles. The COVID-19 pandemic over the past year (2020) has also had a major impact. Beyond the illness, fears and psychological anxiety caused by the pandemic, we are also exposed and required to adopt behaviors that are foreign to us: "masquerading" with face masks, "chronic" hand washing and most of all - social distancing. These run counter to fundamental human nature that seeks warmth and human closeness. Social distancing is especially difficult in a country like Israel, where one of whose basic features of life is togetherness, and especially in Israel's warm Mediterranean climate where people tend to spend their leisure time together outdoors (Davidovitch \& Lazar, 2017).

\subsection{Importance of the Problem}

The dictates of social distancing appear to be difficult for virtually all sectors of the population, as attested by the violations, parties, and large-scale celebrations in Israel, or the political election rallies in the United States, for example. However, it seems to be even more difficult for us as Israelis and even more for us as Jews. Togetherness is part of our DNA. For example, men are required to pray in a minyan (a quorum of ten men) for many reasons: Fruitful study of the Torah motivated by joy is better in a group, studying the Talmud requires lively discussions of the fine points of Jewish law and is therefore more suitable for two, and there is a well-known saying: "In the multitude of people is the king's honor" (Proverbs 14:28)

In fact, the threat of infection has radically altered the customs of prayer and the synagogue. This is an area that we considered conservative and unchangeable yet has effectively undergone a forced revolution. The synagogue has moved to courtyards, balconies, alleys and building entrance. This change has been accompanied by new customs in the context of praying. One of the positive results is that we often see less ethnic separation among worshipers. Ashkenazi and Sephardic Jews pray together in the same minyan, and so they naturally sing both 
Ashkenazi and Sephardic piyutim (liturgical poems), although sometimes due to the heat, sun, or wind, they shorten their sung prayers. Families have discovered family praying - father, mother, children and perhaps other members of the household pray together on the balcony, something that had been unthinkable in Orthodox society. The piyutim, which had been heard inside the synagogue exclusively, have now emerged into the open air. The connection or accessibility of a public that was far from such poems or from the atmosphere of the synagogue may bring about further changes in the future, which are difficult to predict at the moment (Davidovitch, 2019).

The piyut is a sacred poem that was originally intended to replace the fixed version of a prayer for special days but also on weekdays and celebrations. In later periods, they were written as additions to the fixed versions of prayers rather as than replacements. Piyutim were also written without being intended for any binding liturgical framework - as secular poems. The difference between the secular and sacred piyutim was that the sacred ones had a rich background from the days of the Mishnah and the Talmud, while the secular ones emerged in an empty space, with no previous background.

\section{Method}

The study utilizes qualitative research methods, including:

1. Examination of primary sources: prayer piyutim, medieval Hebrew poetry from Spain

2. Comparative analysis of authors (religious, traditional, and modern) in different periods (past and, present) and places (Europe, North Africa, and Israel).

In this article, we illustrate this phenomenon of combination between tradition and modernity: Judaism on the move, which, is taking place before our very eyes in Israel, through several defining examples: piyutim and songs from over the years, various composers and performers who made their way into general music. In a world of alienation and social distancing, the religious piyut stands out, like its secular counterpart, which is designed to express the connection between man and his Creator, but no less to give vent to the various emotions that overwhelm him, with the connection between text and melody turning these poems into a melody of the heart. The origin of the surprising phenomenon, apparently, is in the emotion inherent in these piyutim that pour soothing oil on a heart thirsty for connection and emotion.

\section{Results}

The beginning of this phenomenon is part of the prayers of Israel in the third, fourth, and fifth centuries, the period of the piyut by anonymous composers. This writing is characterized by sublime writing using elaborate language, texts with depth and thought.

These connections, to which we have recently been exposed, come at a time when the secular public is also developing somewhat of an affinity to modern Hassidic singing (Rubin, 2000). Hassidic music is a genre of Jewish music that includes religious songs and tunes sung by members of the Hassidic Movement, in which music was attributed a significant role in God's work.

Although we have been familiar with Hassidic song festivals since as early as the second half of the twentieth century, they too had a precedent in Ish Hassid Haya (There was a righteous man), a play based on Hassidic songs, which was staged in 1986.

When this play was staged, Israelis in the modern world flocked to the theater to hear traditional lyrics from Jewish texts. In recent years, the phenomenon has intensified and even undergone a transformation. Religious singers have become popular with the general public, and while the lyrics are not taken exclusively from Jewish texts, they remain in the spirit of tradition and faith (Novak, 1968). Lyrics taken from Jewish texts and personal lyrics that are not sacred but are influenced by the spirit of Jewish texts have become the new piyutim. Following the birth of the new piyutim, modern paytanim, also emerged: some are observant, some are non-observant Jews, and some are newly religious.

The paytan, i.e., the man who sings the piyut, can be the author, rabbi or cantor approaching the Ark of the Covenant who conducts the prayers of Israel.

Some compose and sing actual religious piyutim and some write new lyrics in a traditional spirit. Sometimes these are the words, sometimes the words and the melody and sometimes mainly the melody.

These piyutim have ancient and deeply-rooted sources. Those from the past were originally Jewish liturgical poems, songs for the synagogue, man's song for his God, and the congregation's song for God. However, personal piyutim also emerged in the past. These could also be secular songs describing a specific state of mind, a song for a loved one, or a lament over a lost friend (Davidovitch, 2019). 
A piyut is chanted by the individual as a prayer, supplication, thanksgiving, praise, or as a secular statement glorifying nature, love, wine and feast, originating in man's need to pour out his heart and express his emotions. These are often accompanied by music - a melody. It is well known that poetry is rooted in emotion, with music being the most emotional art (Huxley, 1931), the one that pulls on the heartstrings.

Music is known as one of the world's oldest art forms. The Bible also mentions Jubal as the father of art: "he was the father of all such as handle the harp and organ" - the first musical instruments (Genesis, 4:21). The word "music" is derived from the Greek word mousike, "the art of the Muses", meaning unity between sound, word, and movement. The Greek term had a broad use that included the arts presided over by the nine Muses, all the branches of education aimed at mental development versus physical development (Encyclopaedia Hebraica, p. 538). In the ancient world, music was a broader concept than the one known today and it referred to the universal language of nature. Audible sounds are considered an expression of the divine order - the harmonious laws and relationships that make up the universe. This order is reflected in the arts of the Muses - music, dance, theater, architecture and more.

Poetry and music have also had a place of honor in the history of the Jewish people, with climaxes such as the singing of the Levites in the Temple, the songs of the Golden Age in Spain or the Hasidic melodies of the eighteenth century (Marks, 2014). Like the piyutim of the past, Hassidic music, with its mix of sad and happy melodies, expresses longing for the glorious past and hope for redemption from the difficulties of life in the Diaspora. It is generally based on one prolonged sound, and its lyrics it contains a single word or meaningless syllables intended to express to God a feeling "too delicate or too intimate to be expressed in an ordinary verbal utterance" (Encyclopaedia Judaica, p. 676). It was the Baal Shem Tov, the founder of the Hasidic movement (1690 - 1760), who first referred to the Hassidic melodies in this manner - an attitude that his students continued, especially Rabbi Shneur Zalman of Liadi, founder of the Habad movement. This music devoted special attention to its connection with ecstasy.

In her book Unity of Opposites: The Mystical Theosophy of Habad, Rachel Elior notes that there are two souls that make up the human mind: the animal soul and the divine soul. The first represents the orientation to the overtly earthly and physical, while the second represents the orientation to ascend to the hidden divine essence (Elior, 1993).

The disciplines of literature and art are rich in contexts and connections to the discipline of music. The Yiddish writer best known by his nom de plume Shalom Aleichem, for example, described his experience as a child listening to the violin: "I heard singing, sighing, crying, whining, talking, roaring - all sorts of strange noises I had never heard before. Sounds as sweet as honey, as smooth as oil, continued to flow straight into my heart. My soul soared far, far into another world, into a paradise of pure sound" (Rabinovich, 114).

Johannes Vermeer's painting The Music Lesson is a well-known work of art. The motto on the lid of the virginals played by the young woman reads: "Music is the companion of joy, balm for sorrow." The connections between the arts are so well known and researched that they have been called "sister arts" (Hagstrum, 1974, p. $13)$.

This article illuminates an interesting social, cultural, moral and human phenomenon, which has been developing in Israel since the 1980s, and is now intensifying during the COVID-19 era. The ancient piyut, written in archaic and lofty language, reaches the general public and finds expression in new musical arrangements. We have encountered a similar phenomenon in Italy, for example, which has been hit hard by the COVID-19 pandemic. Balcony singing has developed there. The Land of the Boot, known for its famous traditional operas and arias, is overflowing with popular renditions of these operas and arias along with light music.

Interestingly, in Israel this phenomenon occurs in the transition to prayer in courtyards and on balconies, the sites that replace the traditional synagogue during the COVID-19 era. Nevertheless, these prayers and piyutim occupy a place of honor not only in religious poetry but also in general poetry, which is remote from the synagogue. Prayers and whole piyutim, parts of piyyutim and words inspired by them now occupy a place of honor in secular culture in Israel and in Jewish communities abroad.

\subsection{Main Landmark: Muslim Spain (Andalusia)}

The piyut was at its peak during the Golden Age in Spain. Poems between man and his Creator and between man and his fellow man reached their literary-artistic peak in Andalusia in Muslim Spain (Perlson, 2006). In the tenth century, Spain was a flourishing center of Torah learning and Jewish culture where piyutim emerged. But unlike the other centers this Sephardic center completely revolutionized modern poetry with its innovation, secular poetry, poetry for its own sake, whose content mainly concerns the relationships between people, between man 
and his environment, and between man and himself. These poems gave expression to the world of the individual, his feelings, dilemmas, and thoughts. The innovation of the Spanish piyut was that for the first time the same paytanim who wrote religious songs also wrote secular songs (Pedaya, 2013).

They included themes that have nothing to do with the world of prayer or the world of the synagogue: poems of wine and poems of desire, poems of complaint, poems of friendship, poems of thought. These themes did not evolve endogenously in Hebrew poetry, they are rather the fruit of the connection and proximity to Arab culture, and as a result is a reflection of the historical and social circumstances of that era (Hazan, 2007). The most prominent expression of innovation in Spanish poetry is associated with the name of Dunash ben Labrat (Pedaya, 2013). Dunash (920-990) was born in the city of Fez in Morocco. From there he moved to Baghdad, a center of Torah learning and science, and studied Torah under Rabbi Saadia Gaon (882-942). He then moved to Spain. Dunash composed piyutim and holy songs including the famous song for the Shabbat, Dror Yikra. The piyut became popular across the various Jewish communities outside Spanish and is considered one of the most popular genres in Jewish communities in all ages for Shabbat and for weekdays.

We will present some examples of the prominent poets of the Golden Age in Spain, whose piyutim are sung to this day. In addition, the words of prayer and the piyut of yesteryear have received new interpretations that are expressed in music and poetry (Beeri, 2008).

Shmuel HaNagid (Cordoba 993 - Granada 1056) - one of the greatest poets of Spain, who made an enormous contribution to the development of Hebrew poetry in Spain. In the past generation, some of his songs were set to music, and one line from his wine poem, "Av is dead, so too Elul, no longer will they warm / So too was Tishrei gathered unto them" was included in the opening of a modern song written by the poet Natan Yonatan (1923 2004), and has been sung by many up to date. The wine song, originally a song of joy by Shmuel HaNagid, has become a modern lament with a new interpretation of expressing pain and sorrow over the death of Yonatan son.

Rabbi Solomon Ibn Gabirol (Rashbag), a young contemporary of Shmuel HaNagid, competes with Rabbi Yehuda Halevi for the title of the greatest of the Spanish poets $(1021-1058)$. Despite his short and hard life, Rashbag left the Jewish national a legacy in the form of an abundance of magnificent lyrical poetry comprising both secular poetry and sacred poetry. Many of his piyutim have been included in the traditions of various Jewish communities. His songs are known in many settings, such as the song Shalom Lecha Dodi. This one was originally a sacred poem, in which the People of Israel turn to God for redemption. The modern poem immortalized the same text, but with a completely different meaning. The female character addresses the male character, her beloved. Thus, the poem turned into a courtship poem, with a woman wooing a man.

Rabbi Yehuda Halevi (Rihal), a young contemporary and close friend of Moshe Ibn Ezra (1075 - 1141) is considered by many to be the greatest Spanish poet. His poetry captivated people from the beginning of his career as a poet, and poetry lovers copied and preserved his poems, both sacred and secular, thereby granting his poetry a place of honor in every prayer book in every Jewish tradition and in every setting. Today we are witnessing an interesting phenomenon - his poem Tziyon HaLo Tishali, written as a personal poem in praise of the Land of Israel, was included in the Order of Lamentations and became an example for many lamentations that followed and imitated it. This influence of Rihal's poem and of Tziyon HaLo Tishali continued to modern Hebrew poetry, and the line 'Not to all your poems I am a violin' in Naomi Shemer's song (1930-2004), Jerusalem of Gold, is based on the stanza in Halevi's poem: "But when I dream of the return of your captivity, I am a harp for your songs". Rihal's lament, in the phrase that he coined, "I am a harp for your songs", continues to resonates years later and finds expression, consciously or unconsciously, in the line of the iconic song, Jerusalem of Gold: "I am a harp for all your songs", despite the distance of generations and completely different mindsets. The poem of lamentation and longing became a song of praise for the building and revival of Jerusalem.

Moreover, about a decade ago, the Israeli singer, Etty Ankri (1963) abandoned protest songs with sophisticated melodies and began setting Rabbi Yehuda Halevi's piyutim to music. It is possible that her return to this genre is part of the exciting Jewish renewal of this generation. Ostensibly, Ankri gave up the stinging words, the protest, and the personal exposure and discovered, in turning to her roots, another equally powerful embodied world.

Notably, these melodies, of texts written centuries ago, have won gold albums: They have listeners, they have an audience. They address a broad, diverse, multi-ethnic audience - religious and secular, East and West and observant Jews who have no problem singing with women and non-Jewish artists.

It should be noted that many of the piyutim written in Spain are anonymous. Sometimes the poet signed his name in the first letter of each line from the poem, in the form of an acrostic. In the Middle Ages, the acrostic was considered one of the ornaments of the poem, and the more complex and elaborate the acrostic, the more it added 
to the prestige of the poem and its author. Some important and famous holy books began with the acrostic of the letters of the name of God (the tetragrammaton), such as Maimonides' book, Mishneh Torah, which opens with the words "The foundation of the foundations and the pillar of wisdom".

Synagogue singing constitutes the cultural infrastructure of every Jewish community, in Europe, the USA, Africa, and Asia. This pattern is also relevant for the distant country of Yemen.

Now we proceed to discuss the piyut in Yemen, and how the works of the greatest Jewish Yemenite poet, Rabbi Shalom Shabazi, were received across the world, as well as the contribution of the late contemporary singer Ofra Haza (1957-2000) - who sang them in a language far from the original - in English. Ofra Haza, a singer who was connected to her yamen roots, was a groundbreaking performing artist abroad. The singer who amazed everyone when she came in second at the 1983 Eurovision Song Contest in Germany, with the song Chai, turned a centuries-old text of Rabbi Shalom Shabazi into an international hit song, and was the first Israeli singer to receive a Grammy nomination. She turned piyutim into iconic Israeli songs, thanks to her performance. She brought the tradition of home, the special Yemenite poetry, into the Israeli mainstream, and even achieved international success.

\subsection{Characteristics of the Modern Piyut}

1. The piyutim are no longer taken from prayers only or incorporated into prayers. They are written for specific occasions, for the Sabbath and holidays and for family celebrations: circumcisions, bar mitzvahs, weddings, etc.

2. The poets write their poems to be sung. They typically choose a well-known melody familiar to the members of the community.

3. The language is simpler and more popular than that used in prayers or Spanish poetry. The poets utilize all layers of the Hebrew language and write both in ancient Hebrew and later styles, in the style of the Bible and that of the literature in the Middle Ages, and in Aramaic. They believe that any aspect of the Hebrew language deserves to be used when writing poetry.

4. This poetry is also innovative in the type and content of the songs, with considerable emphasis on the themes of the Diaspora and redemption. The longing for the Land of Israel.

5. Expanding time and place - piyut performances such as concerts - and synagogue singing - have become performances in theaters and parks. From the synagogue - to Israel - to the world

6. Use of technology - TV, YouTube...

Avraham Fried (1959), an American member of the Chabad community, is one of the most prominent singers and songwriters in the Hassidic music genre, and is considered one of the greatest Hassidic Jewish singers. He began his musical career in the early 80s and released dozens of albums including songs that became hits. His studio albums became platinum and gold albums.

7. New Mission - not only between man and God but:

- To be the bridge between the world of the original piyutim of the past and the world of contemporary music (jazz, pop).

- To bring the piyut to the forefront of the stage in Israel and around the world - the new songwriters have brought these poems into the mainstream.

- To bridge the gap between East and West - openness - back to the roots, to the childhood home - Mizrahi piyutim have been heard by almost everyone in Israel.

- To bring young people together - the seeds sown from the 1990s onwards paved the way for successful contemporary artists who fill theaters with religious music.

- To strengthen the power of community singing.

- To strengthen identity - the World Piyut Festival, TV competition: "The Paytan" - piyut as part of a cultural experience, as a component of Jewish, Israeli - global identity (ethnic poetry)

The following example is constitutive in terms of the duality of the modern Israeli songwriter and the modern Israeli person, in terms of the combination of old and new, sacred and secular, with both performers of the poem also coming from these two worlds.

\subsection{Between Sacred and Secular - Between Tradition and Modernity}

Between Sacred and Secular is a song composed by a young composer named Shachar Hadar. The song was 
released on September 22, 2019, and managed to penetrate the hearts of Israelis, both secular and religious song capable of bringing people together.

"There in the place from whence I came there is no peace, and this journey is onerous and a little too much for me

I have to grow from this and enough growing from this and enough, please take care of me, just so my feet do not fail me

Between reality and insanity everything comes back to me

Even in the place from whence I came there is no peace

And this journey is onerous and a little too much for me, I have to grow from this and enough - I live between secular and sacred".

The old piyut Between Sacred and Secular receives new music and finds its way to the heart of prayer, to the synagogue. One example is the piyut U'netanneh Tokef.

\section{U'netenneh Tokef-about the piyut, the music and the paytan: old and new}

The piyut traveled a long way from ancient times to the Spanish exile and from there to the kibbutz, to the legendary Gevatron choir and its soloist Hanoch Albalak, who becomes a modern paytan here. A singer who comes from the kibbutz experience, devoid of religion, pours out his heart to the Creator of the Universe.

Singer Hanoch Albalak's moving rendition of the prayer song 'U'netanneh Tokef' has become a classic and an inalienable asset in Israeli culture. The song became the most widely broadcast Yom Kippur prayer in the media. In the 1990s, Hanoch Albalak joined the Gevatron, and his rendition of the song 'U'netanneh Tokef' was included in the choir's regular program. This unique melody (1990) by Yair Rosenblum (1944 - 1966), was inspired by the death of 11 members of Kibbutz Beit Hashita in the Yom Kippur War. The kibbutz was the symbol of the new and working State of Israel, in contrast to Jews concealed in a house of worship.

'U'netanneh Tokef' is considered one of the most well-known and popular piyutim for the Days of Awe and Jewish prayer in general. It describes the great fear of the wrath of the God of Israel, and the nothingness of man before him. A twelfth-century tradition attributes it to an eleventh-century figure, Rabbi Amnon of Mainz (Regev \& Seroussi, 2004). A copy of it exists in the Cairo Genizah, dated to the tenth century at the latest.

Another interesting story in the context of this piyut is the story of the Malavsky family. The Malavsky family, a Jewish-American family that has performed throughout the Jewish world in prayers and programs of Jewish cantorial music and folk music. The father, cantor and composer Shmuel Malavsky (1894-1985) was the soloist of an ensemble called The Singers of Israel, accompanied his four daughters and two sons.

It is a revolutionary step for a cantor who considers himself Orthodox to include women in singing cantorial verses and in particular prayer itself, since Jewish law forbids men from hearing women voices in song. Orthodox synagogues refused to allow Malavsky to pray accompanied by a mixed choir, yet he was not interested in a position at Conservative synagogues because he felt that the customary prayer style has changed in a way that unacceptable to him as an Orthodox Jewish man.

However, the combination was well received by the public. The Malavsky family performed in concerts throughout the United States and around the world, singing cantorial verses, Jewish folk songs, jazz songs in Hebrew, Yiddish and English, and even prayers, generally held at halls and hotels rented for this purpose.

Shmuel's daughter, Golda Malavsky, became famous as a singer, and performed alone or with her sister Gitelle as the Marlin Sisters duo in the 1940s. They even performed with Frank Sinatra. Golda's recorded concerts and cantorial verses earned her the reputation of a "cantor" in her own right, although she never led a congregation in prayer.

The Malavsky family made several records of cantorial verses and Jewish folksongs, which became hits throughout the Jewish world. Their most famous song among the general public was "Haben Yakir Li Ephraim", with the girls as soloists. Many cover versions of this song have been promoted.

Artists who displayed interest and involvement in what was happening in the general Jewish artistic world operated in the 19th and early 20th century. Sages and their students began to publish piyutim and secular poetry, and research on these poems flourished. So-called Zionist writing is an important theme in the writing of piyutim in the 20th century, which introduces the theme of exile and redemption into these works. In other words, the dreams and prayers comprising them now have another more practical interest as well, when the traditional piyut encountered poetry known as Hibbat Zion, written in Europe and published in Hebrew-language publications that reached the East (Seroussi, 2001). 
It is interesting to examine the world of 20th century piyutim in light of the emergence of new Hebrew poetry. The relationship between the two types of poetry is complex and raises many questions regarding their content, conceptualizations, and socio-cultural dimensions. It seems that the relationship also evolved over the course of the century, sometimes becoming more similar, and other times, more different (Stokes, 1994).

Communal singing in public. Everyone can do it.

\section{Discussion}

The piyut initially existed throughout the times of the bible and the Jewish Diaspora, especially in synagogues as sacred poetry. In addition, they also involved into secular poetry and even into poetry of desire and wine. From their It found it place in the renewed culture of the State of Israel, in shows, concert halls, song contests, on records, on the radio and on TV - and in performances all over the world.

This study shows that, surprisingly, even the younger generation, which speaks a new and more technological language, which tends to reject the "heritage of the forefathers" and make its own way - connects to ancient words and melodies. The young songwriters are leading a revolution in connection with tradition, from this aspect, and in the connection between old and new, and it has been found that there is a wide audience that is thirsty for these materials (Shiloah \& Cohen, 1983).

Prayer has become the poetry of the masses, using less lyrical language and more everyday Hebrew, as expressed in the poetry of contemporary writer, Talma Alyagon (2001):

We will sing in our hearts, we will sing in pain, we will sing all our hopes

We will sing together, we will integrate, and we will bridge hearts.

Songs whose sounds are tears, we will sing for hours and hours

Songs in the spirit of lightness, the singing of many is a prayer.

A sea of songs captured within me, like stars in the sky

And the waves of the sea in them, the sun and the mountains, my dreams are also there, the grace of youth.

When we sing together - our hearts connect on their own.

Every song is woven into the carpet of my life, every song brings longing

A song that your face and face are engraved in, a song that makes you want to cry over you and me.

When we sing together - the heavens above shine.

A song that removes a tie, and opens hearts

A song that evokes a smile and love, a song that jokes, a song from the army.

When we sing together - the mountains around us are thundering.

This is how we pour out our hearts, this is how we touch the sky

This is how we heal our souls from pain, this is how we hold on to time in its flight

When we sing together - our hearts connect on their own.

We will sing in our hearts, we will sing in pain

This recent and unique phenomenon illustrates how the nation is "renewing its days of old" and has many implications. Religion and tradition constitute an anchor for connection, for a sense of belonging and identity, for an intergenerational cultural connection, and for values encompassing the tolerance, pluralism, and openness that are very necessary today. This study has educational implications for intergenerational relationships, for creating a cultural connection with our roots and with the traditions of our forefathers, for preserving symbols, values, and behavioral norms that respect and appreciate works that transcend time and place.

Koolulam is a social-musical initiative for public singing.

The initiative was established in 2017 and aims to strengthen society by strengthening the ties between the people who make it up and do so through public singing. The project team organizes mass singing events in which large groups of people (usually, 1000 people or more) without any musical background come together to create a joint musical work. Well-known songs are chosen for the Koolulam events, and are given a new vocal and instrumental arrangement. During the event, the audience is divided into groups according voices, the conductors teach them their parts in the song within a short time and then they all perform the song together. Koolulam events are recorded and filmed by a musical and cinematic team, and after the event, a video clip is distributed on social media. 
For the commercialized, industrialized generation, in an era that has the potential for social isolation, the words and melodies of yesteryear become voices and sounds with the potential to speak to the soul of modern man per se. There are many more challenges ahead: How can we create a sense of togetherness in our mass prayer in the challenging time ahead? The experience of togetherness Around the World and in Israel, across sectors and genders.

\section{References}

Beeri, T. (2008). The work of Prof. Ezra Fleischer in the study of Hebrew sacred poetry in the Middle Ages Some Aspects. Jewish Studies, 45, 135-146.

Davidovitch, N. (2019). The function of the synagogue in leisure culture. Philosophy Study, 9(1), 1-15. David Publisher. https://doi.org/10.17265/2159-5313/2019.01.001

Davidovitch, N., \& Lazar, A. (2017). The Sabbath, the synagogue, and leisure culture: Jewish tradition and modernity. US-China Education Review A \& B, 7(3), 159-165. David Publishing Company. https://doi.org/10.17265/2161-6248/2017.03.005

Elior, R. (1993). The paradoxical ascent to God: The Kabbalistic theosophy of Habad Hasidism. The State University of New York Press.

Encyclopaedia Hebraica. The art of the muses (Vol. 22).

Encyclopaedia Judaica. (2007). The Hasidic Niggun. Keter.

Hagstrum, H. J. (1974). The sister arts. University of Chicago Press.

Hazan, A. (2007). What is a piyut? Definitions and history. Invitation to a piyut. Retrieved from http://www.piyut.org.il/articles/529.html

Huxley, A. (1931). Music at night and other essays. Doubleday Doran.

Marks, E. (2014). Social and cultural aspects in the revival of religious songs in Israel. Retrieved from https://in.bgu.ac.il/bgi/iyunim/music/Essica-Marks.pdf

Novak, H. (1968, October 3). Hassidism with an electric guitar. Davar.

Pedaya, H. (2013). Introduction to the understanding of the piyut, invitation to a piyut. Retrieved from http://www.piyut.org.il/articles/134.html

Perlson, I. (2006). Great joy tonight: Jewish Arab music and oriental identity. Resling, Tel Aviv.

Regev, M., \& Seroussi, E. (2004). Popular music and national culture in Israel. University of California Press. https://doi.org/10.1525/9780520936881

Rubin, R. (2000). Voices of a People: The story of Yiddish folksong (3rd ed.). University of Illinois Press.

Seroussi, E. (2001). From court and tarikat to synagogue: Ottoman art music and Hebrew sacred songs. In Transactions: Sufism, Music, and Society in the Middle East. Curzon. Istanbul

Shiloah, A., \& Cohen, E. (1983). The dynamics of change in Jewish oriental ethnic music in Israel. Ethnomusicology, 27(2), 227-251. https://doi.org/10.2307/851076

Spradley, J. P. (1979). The ethnographic interview. Harcourt Brace Jovanovich College Publishers.

Stokes, M. (Ed.). (1994). Ethnicity, identity and music: The musical construction of place. Berg.

\section{Copyrights}

Copyright for this article is retained by the author(s), with first publication rights granted to the journal.

This is an open-access article distributed under the terms and conditions of the Creative Commons Attribution license (http://creativecommons.org/licenses/by/4.0/). 